\title{
Commodification, decolonisation and theological education in Africa: Renewed challenges for African theologians
}

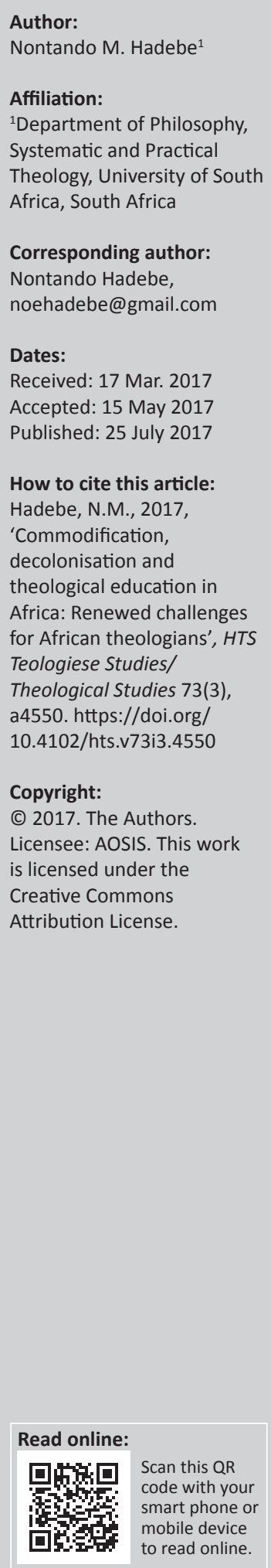

The commodification of higher education is a global phenomenon that many argue has reduced education into a product that serves the interests of global capitalism and perpetuates the hegemony of western knowledge. Decolonisation discourses demand for access and an Africanised curriculum constitutes resistance to commodification. Theological education as part of higher education has not escaped commodification. African theologians pioneered resistance against the hegemony of western theologies. However, there are additional factors driving commodification, such as high demand for training, that outstrip supply because of the phenomenal growth of Christianity and rise in Christian consumerism. African theologians therefore need to continue resisting western hegemony and also pursue critical dialogues with decolonisation movements as well as all stakeholders such as churches, government and civil society as resistance to commodification. The inclusive and communitarian methodology of the Theological Colloquium on Church, Religion and Society in Africa will be critically assessed for its potential as a possible model.

\section{Introduction}

\begin{abstract}
Higher education is now being exported from one country to another, particularly from the United States. Extension centres, branch campuses, franchising operations, and various other 'transnational' higher education arrangements have become commonplace. For example, much of what is happening in and through the rapid spread of Evangelical or Pentecostal theological education is reflected in the shortage of uncontextualised teaching material and curriculum plans. (Werner 2010 in Naidoo 2013:5)
\end{abstract}

The 'trading' in higher education described in the above quotation is one way in which commodification has transformed education into a product whose value lies in its marketability. Universities are turned into business enterprises that produce graduates for the market as well as export knowledge globally through online courses, franchises and satellite campuses. Similarly, students are reduced to consumers paying high prices for education in exchange for degrees that guarantee employment. In this milieu, universities serve the market. Opponents of these developments argue that utilitarian market-driven education violates the raison d'être of a university, which includes preserving the intrinsic value of knowledge, formation of students into critical thinkers who are competent in their disciplines and agents of social transformation (O’Byrne \& Bond 2014; Miller 2003; Sall \& Ndjaye 2007; Schwartzman 2013; Yang 2006). However, former colonies face additional challenges because the 'product' traded in higher education is western knowledge that further entrenches its hegemony that was established during the colonial and apartheid eras. Consequently, identity, Africanisation, contextualisation and decolonialisation represent resistance in pursuit of transformation that serves the wider social context and not the narrow interests of the market. Theological education in Africa is embedded in this context and therefore faces similar challenges. African theologians pioneered resistance to the hegemony of western theologies through inculturation, liberation and black and women's theologies. There are additional factors contributing to the commodification of theological education, which include dramatic changes in the demographics of Christianity as indicated in the above quotation that has resulted in the high demand for theological training, the proliferation of 'imported' courses and Christian consumerism. These developments present renewed challenges for African theologians to continue resisting the hegemony of western theologies by serving the 'market' of the wider social context through-as will be argued in this article-theologies developed in dialogue with stakeholders in the commodification process including decolonisation discourses, churches, higher education, government, business, civil society, students, laity and academics. Accordingly, the inclusive, conversational and communitarian dialogue across differences as a theological 
method adopted by the Theological Colloquium on Church, Religion, and Society in Africa (TCCRSA) (Orabator 2012) will be proposed as a possible model. The TCCRSA brought African theologians primarily from the Catholic Church into dialogue with stakeholders within and beyond the Catholic Church. Furthermore, the TCCRSA significantly identified itself in continuity with Vatican II, the twenty-third ecumenical council which through a much wider inclusive dialogical process produced sixteen documents that transformed the Catholic Church without changing dogma. Thus, the contextual and multi-faceted theological characteristic of Vatican II provided the framework for a similar process by TCCRSA that produced four books as a contribution to the transformation of theological education through critical recovery of the mission of the Catholic Church in Africa. The rest of the article will discuss these issues further beginning with the commodification of higher education, theological education, Christianity as context for a dialogue between African theologies and decolonisation discourses that will frame the critical analysis of the methodology of TCCRSA as a possible model for generating theologies that counter commodification and recover the mission and purpose of theological education in Africa.

\section{Commodification of higher education, theological education and Christianity in Africa}

According to Merriam-Webster dictionary, to commodify means to 'treat something that cannot be owned or that everyone has a right like a product that can be bought and sold'. ${ }^{1}$ Jacobs (2009:393) quotes Karl Marx's definition of a commodity as 'an external object, a thing which through its qualities satisfies human needs of whatever kind'. The range of commodities is as varied as human needs; for example, food, entertainment, spirituality, God, information, education, etc. Two qualities that transform an object into a commodity is that it has value and can be exchanged for money, priced or traded (Jacobs 2009:393). Similarly, commodification of knowledge transforms knowledge into a commodity that is 'deliberately stripped of context and subjectivity, so that it can be communicated, traded, used and applied by anyone anywhere'. ${ }^{2}$ Education, for example, is both a human right and a public good, which when commodified loses its essence and identity.

\section{Commodification of higher education in the global context}

Commodification in highereducation is a global phenomenon. In Britain, for example, O'Byrne and Bond (2014) describe three models operating in higher education: intellectual, managerialist and consumerist. The intellectual model representing academia argues for the preservation of the traditional role of the university as described below:

The university is not a business, nor is it a feeder to the marketplace, but is rather a space of intellectual engagement, in

1.https://www.merriam-webster.com/dictionary/commodify

2.http://www.igi-global.com/dictionary/commodified-knowledge/34665 which the chief values are the inherent value of knowledge, free and critical thinking, diversification and disciplinary integrity, and a passion for scholarship and research. (p. 577)

In contrast, the managerialist model supported by government, funders and policy-makers maintains that the university should be run like a business enterprise with checks and balances to ensure quality control, financial viability and alignment with the needs of the market (O'Byrne \& Bond 2014:577). The consumerist model supported by students, parents and business is characterised by the 'rhetoric of employability and skills' and 'market-driven obsession with vocationalism' (p. 577). The managerialist and consumerist models share a functional and utilitarian view of the university in contrast to the intellectual model with its emphasis on the intrinsic value of knowledge, research, freedom, disciplinary formation and social responsibility. Yet these models despite their differences make distinctive contributions to higher education. For instance, the ideals of the intellectual model in valuing the intrinsic value of knowledge and social responsibility need not necessarily contradict with the ideals of managerial and consumerist models of ensuring quality, market-driven courses and employability. O'Byrne and Bond propose 'a tripolar paradigm, in which each of the three models operates not in contradistinction to the others, but in coalition, such that the contradictions are ironed out and a minimalist consensus is achieved' (p. 581). Another central issue is the exclusion of knowledge and experiences of racial minorities. For example, the recent campaign at University College London entitled 'Why Is My Curriculum White?' 'aims to grapple with an academic curriculum in which a white voice is overbearing and all-permeating' (Tehram 2015:1). These injustices in higher education are foregrounded in the quest to serve the market.

The foregoing three-model paradigm described by O'Byrne and Bond (2014) characterises the global discourses on commodification in higher education, for example, in China, the United States, Russia and Africa. Yang (2006) describes education as 'the most profitable industry in China, second only to real estate' (p. 60). As a developing nation with large poor communities, commodification denies many students access to higher education and opportunities to improve their lives, an issue of social injustice because:

Public education is a public good. It is one of the principle means available to foster a deeper and more harmonious form of human development and thereby to reduce poverty, exclusion, ignorance, oppression and war (Delors 1996). As a public good and a contribution to the development of a just society, education is important to all. (Yang 2006:65)

Further commodification comes with the uncritical adoption of western knowledge, which marginalises local customs and traditions. For example, education in traditional Chinese culture emphasised formation and social responsibility: 'The fundamental purpose of education is to cultivate students' moral character and teaching is more than a job, indeed seen as something of a calling' (Yang 2006:62). 
In the United States, according to Miller (2003), corporations have increased their investment in universities and restructured these into business enterprises that transfer costs to students:

we can see a tendency across the entire degree-granting sector of transferring the cost of running schools away from governments and towards students, who are regarded more and more as consumers who must manage their own lives, and invest in their own human capital. (p. 901)

Schwartzman (2013:1) argues that the social contribution of education is replaced by the 'amoral marketplace [which] contrasts with the ethic of mutual care that lies at the core of responsible citizenry'. Similar to the UK experience, minority groups such as African Americans continue to protest against their exclusion (West 1993).

The Russian experience of commodification in higher education includes the loss of the formative and social aspects of education as argued by Karpov (2013), which has proved to be counter-productive to the production of knowledge, a critical component of all universities:

And so, the conceptualisation of education in the terms of 'commodity' and 'service' eliminates from its didactic basis the methods and content that form the kind of creating individual who possesses an inquisitive attitude toward reality, that is, the kind of individual who is able to create knowledge. (p. 79)

Higher education in Africa faces similar challenges, which are compounded by the hegemony of western knowledge and economic inequalities inherited from the colonial and apartheid eras. Whitt (2009) describes western knowledge as anti-pluralist:

The dominant knowledge system tends to embrace an antipluralism, a lack of receptiveness to alternative epistemologies, to other ways of knowing the world. Other knowledge systems are usually reduced to 'superstition, the very antithesis of knowledge'. (p. 32)

African as well as other Indigenous knowledge in former colonies was denied legitimacy and excluded from the entire colonial education system. Mbembe argues that 'this hegemonic tradition has not only become hegemonic. It also actively represses anything that actually is articulated, thought and envisioned from outside of these frames' (Mbembe 2015:9). Consequently, identity, Africanisation, contextualisation and justice are some of the additional critical issues central to the transformation of tertiary institutions into a public good responsive to the multiple challenges in contemporary Africa. Hence, Makgoba and Seepe (2004:14) argue that the quest for identity needs to be informed by a vision 'of a new paradigm that locates the African condition, knowledge, experiences, values, worldview and mindset at the centre of our scholarship and knowledge-seeking approach'.

The foregoing brief overview of some of the contested areas in the commodification of higher education globally serves as a background for commodification of theological education and Christianity.

\section{Commodification of theological education in Africa}

The parallels between the experiences of commodification in higher and theological education may seem like an anomaly because of some differences between the two, particularly in relation to the type of students, mission and purpose. Most of the students who enrol in theological institutions do so because they are responding to a call from God to ministry or priesthood in their churches. Thus, theological education at its most basic level serves to prepare them for these roles in their churches and communities. There are different definitions of theological education. Wahl identifies five models of theological education in the global literature as 'the classical model; vocational model; dialectical model; neo-traditional model; missional model; and ecumenicaldiversified model' (Wahl 2013:273). Each model focuses on different aspects of theological education. For example, classical models define theological education as 'primarily concerned with the intellectual and moral process of the Christian faith in order to get cognitive wisdom' (Wahl 2013:273, 284), while the ecumenical-diversified model aims to 'provide contextualised and diversified theological education' that allows for greater 'access to theological education in order to equip all God's people to be able to meet the contextual needs and development of their immediate social and ecumenical context' (Wahl 2013:288). The capacity to respond to social context is critical for ministers and priests today. Naidoo notes that there is a 'growing need for ministers to interpret the socio-economic, cultural, political and spiritual context of the majority with the aim of transforming these contexts' (Naidoo 2013:6). Equally important is the formation of students that cuts across all these models. Naidoo describes formation as 'a multi-faceted activity involving critical thinking, the acquisition of knowledge, skills development, religious identity formation and the development of ministerial and spiritual maturity expected of church minister' (Naidoo 2015:3). Similarly in the Roman Catholic Church, Pope Paul VI (1965) emphasised the multi-faceted training, which includes intellectual competence, for example, in philosophy, Latin, human sciences, tradition and scripture whose goal is Christological formation: 'the entire training of the students should be oriented to the formation of true shepherds of souls after the model of our Lord Jesus Christ, teacher, priest and shepherd' (Pope Paul VI 1965:n.p.). Theological education therefore needs to prepare ministers and priests who can competently serve their churches and the wider social context. The two are core defining elements of Christian ministry.

However, there are many challenges facing theological education in Africa. Wahl, citing some of the leading scholars in theological education in Africa, lists four current challenges as 'access; the lack of resources; sociopolitical and social-economic illness; and an Africanised scholarship and curricula' (Wahl 2013:269). Amanze (2012) addresses the decline in numbers and research output of theological faculties in universities 
across Africa as caused by: government's quest for social and economic development driven by science, not religion; the abstract nature of theology inherited from western paradigms which fails 'to address contemporary issues affecting the life of Africans in concrete terms' (Amanze 2012); and religious fundamentalism because it is:

opposed to openness and wider interaction with society, does not bring about change. Theologians and Christian leaders coming from fundamentalist institutions do not become catalysts for transformation of our societies. (p. 197)

Venter (2016) and Higgs (2013) reflecting on the South African context address the legacy of apartheid and need for transformation and decolonisation. For Venter (2016):

the quest for transformation of Theology could arguably be contracted in a single denominator: inclusion and epistemic justice. The violence of apartheid is to be found in its exclusionary nature. (n.p.)

The epistemic exclusion in theological education has since its inception been African Indigenous knowledge, gender and lived experiences of Africans. Naidoo (2013) describes the central characteristic of theological institutions in SubSaharan Africa as 'foreignness':

The history of theological education in this region has been characterised basically by foreignness, that is, foreign theological content, methodology and languages. In recent years theological educators have realised the need to take African culture seriously in order to produce a relevant theology for the African people. (p. 6)

One of the consequences of the foreignness of theological education is that it detaches students from their context and compromises their ability to respond to the needs of the parishioners and communities in which they serve. The following remark from Sabelo Ntwasa quoted by Denis and Duncan (2011) illustrates this point:

At present while our ex-seminarian may be able to read his New Testament in Greek and to forward moral arguments for or against extra-marital sex, he is totally unequipped to help his people even breathe under the yoke of poverty. (p. 94)

Similarly Goba, quoted by Denis and Duncan, described an encounter with a student who lamented that 'for three full years ... my Africanness was completely ignored, which reflects the attitude of those who were responsible for theological education' (Denis \& Duncan 2011:94).

Higgs (2013) calls for the decolonisation of theological education in African in order to 'reclaim indigenous African voices through curriculum reforms and the transformation of theological discourse' (p. 43). Women theologians in Africa represented by The Circle of Concerned African Women Theologians have challenged patriarchy, androcentrism and sexism in theological education. Landman (2013:239), quoted by Venter, noted that 'the past thirty years, theological education in South Africa has developed from being white, male and/or denominational to liberational, ecumenical and inclusive of gender, race and belief' (Venter 2016:n.p.).
These issues provide the context for discussions on commodification of theological education.

Commodification in theological education as noted earlier shares some similarities with higher education because it is part of the educational system. The restructuring of education by government policies has impacted theological education. In the South African context, for example, Dunsmuir and McCoy (2013) noted four significant shifts brought about by these changes. Firstly:

a shift from study that has a societal and social value to that which has credit value that can articulate into other academic domains. This can distort the student's goal, which began with a desire to serve in response to God's call to ministry. (p. 33)

The focus moves from ministerial and social vision to meeting assessment criteria. Secondly, the adoption of a business model creates tensions between theological institutions and their church governing bodies who provide funding and students. Thirdly, relationships among peer institutions are negatively affected as cooperation is replaced by competition (Dunsmuir and McCoy 2013:33). Lastly, the regulations mandated by governments impose 'political control by the state and its agencies' through regulations and oversight. Amanze (2012:198-199), in contrast, argues for a positive interpretation of commodification, particularly the development of market-driven curriculum in response to the social challenges on the continent. The market in this case is not business but the multiple social and economic challenges in Africa. Amanze (2012) summarises his point as follows:

There is a need to reformulate the curriculum of theology and religious studies so that it can meet the challenges concerning human rights, economic and political justice, and dialogue between the various sections of society. (Amanze p. 199)

Despite different approaches to commodification, there are common perspectives including a quest for African and institutional identity; transformation of theological education from a western-dominated patriarchal model to inclusive and contextual models committed to social justice, redefining the market for theological education as context not business, formation of students and recovering the mission of theological education.

However, commodification is not only limited to what happens in theological institutions but also in society. For example, the change in the demographics of Christianity and rise in Christian consumerism have contributed to forms of commodification that influence theological education. The phenomenal growth of Pentecostal (local and international) and African Initiated Churches has increased the demand for theological education, which according to Naidoo 'far outstrips the ability of bible colleges, seminaries and correspondence programmes to supply them' (Naidoo 2013:5). This has resulted in the mushrooming of theological institutions and intense competition among them. Naidoo further argues that the: 
entrepreneurial marketing of theological education, valuing the students in terms of what they can consume or produce and the supermarket of theological offerings brings the commodification and commercialisation of theological education into focus. (p. 5)

The competition is further exacerbated by 'imported' overseas courses.

For example from the United States, Rick Warren's How to be a Purpose Driven Church course has been used to train over 700000 pastors worldwide (http://pastorrick.com/about; Einstein 2008:100), and from England, the Alpha course in evangelisation developed in 1990 by Nicky Gumbel is offered in 155 countries, translated into 112 languages and 'runs in every part of the global church, including the Catholic Church, the Orthodox Church and all mainline Protestant denominations' (http:/ /alpha.org/about/; Einstein 2008:107). However, these and other imported courses tend to foreground systemic injustices that underlie personal problems such as poverty and marginalisation:

The social and political policies that make for starving children, battered women, and the evils of rising fascism remain in place as people learn through prayer to find the tranquillity to live with corrupt political and social structures instead of channelling their distress and anger and anxiety into energy for constructive change. (Jantzen 1994:201)

Commodification has compounded the challenge raised earlier for the need of contextual theological education rooted in African realities.

The other contributor to the commodification of theological education is the commodification of Christianity, which will be discussed in the next section.

\section{Commodification of Christianity}

The commodification of Christianity reflects similar characteristics to Einstein's process involved in the marketing of religion which is as follows:

First, in the case of religion, when you market spirituality, you introduce people to the idea that they can shop for it, and so they will, or at least are more likely to. Second, as people are increasingly prone to shop, religions will not only have to increase the level of marketing and promotion in order to be heard among so many competing forces, but they will also be increasingly prone to creating a product that religious consumers will buy. They will change the product to suit the market. Now, this is not to say that religions have never changed with the times. Of course they have. What is different now, however, is the rate at which change occurs. Finally, adding marketing to the mix creates a new goal for religious institutions-growth. (Einstein 2008:xi)

These practices characterise some aspects of contemporary Christianity. For example, people choose which churches they want to attend partly based on the services offered. Churches in turn offer more and more services to attract and retain members. One of the outcomes is the rise of mega churches, which offer a bewildering array of services to their members. To sustain these services, churches have adopted business models. Extensive marketing, branding and fierce competition for members constitute the face of contemporary Christianity. Some pastors have taken extreme measures to keep members; for example, a self-proclaimed prophet sprayed congregants with insecticide claiming that it would heal them (BBC 2016). Healing is one of the key 'products' on offer in many churches. In their research on Pentecostal and Indigenous African churches in South Africa, Anderson and Otwang (1993) found that people were drawn to these churches because of promises of healing:

Healing is one of the reasons why people join these churches, and in several cases it was found to be the main reason. It forms a prominent part of the liturgy of these churches every week, and one can hardly visit a Pentecostal or Pentecostal-type church without observing this emphasis and the rituals associated with it. (p. 71)

In some of these churches, faith healing utilises a range of products such as oil and water that are produced and sold by churches. For example, in the Zion Christian Churches, copper wires, holy water, blue cloths and strings are sold and used for healing: 'strings are tied in various places on the body to procure healing and ward off evil' (p. 77).

To cope with these demands from Christian consumerism, a new brand of leadership is emerging in churches, which De Wet (2013) describes as the 'entrepreneurial pastor', that is, a 'church leader who leads and manages a church, fundamentally incorporating principles of business leadership and managerialism along with traditional pastoral principles' (p. 129). The multiple educational needs of the 'entrepreneurial pastor' require theological institutions to offer a plethora of courses that threaten to overshadow core courses required in the training of ministers and priests such as systematic and practical theology, scripture, church history and contextual liberation theologies.

An additional form of commodification driven by technology and media (smartphones, television, radio and Facebook) is growing rapidly globally and present in Africa. Chris StokelWalke (2017) in an article entitled How smart phones and social media are changing Christianity outlines several ways in which Christianity is being transformed by social media. For example, the growing numbers of Christians who do not belong to any church and access mass or services through live-streaming or downloading podcasts in the privacy and comfort of their home and 'it's no longer necessary to set foot in a church' (Stokel-Walke 2017:n.p.). Christianity is reduced to a private individual practice that is disconnected from its communal identity and commitment to the wider social context. Carrette and King (2005) describe the characteristic in contemporary spiritualities as follows:

In a sense, the most troubling aspect of many modern spiritualities is precisely that they are not troubling enough. They promote accommodation to the social, economic and political mores of the day and provide little in terms of a challenge to the status quo or to a lifestyle of self-interest and ubiquitous consumption. (p. 5) 
Several themes emerge from the foregoing discussions on commodification in higher education, theological education and Christianity. Some of these themes will be discussed further in the next section.

\section{African Theologians in dialogue with decolonisation discourses}

A consistently dominant theme that emerges from the foregoing discussions is the need for institutions of higher learning including theological education to be rooted in African realities and serve the wider social context and not exclusively the market. These goals are shared by both African theologies and decolonisation discourses. African theologies emerged alongside liberation movements in the struggle against colonialism, apartheid and forms of western missionary Christianity that vilified traditional cultures and religions. For example, the first two streams of African theologies were inculturation and black theologies. Bediako (2004:49) describes inculturation theologies as appropriating African culture and pre-Christian religion, while 'Black theology focused on political oppression and employed liberation hermeneutics in an African setting'. According to Martey (1993), these differences are complimentary, not contradictory:

In the African theological reality, the two foci are not contradictory but complement each other. In fact they represent two sides of the same process. Consequently, theological hermeneutics in Africa must necessarily have a unitary perception of inculturation and liberation. (p. xi)

Similarly Bujo (1990) concurs and resists any attempt to separate these streams of African theology:

Can a nation develop culturally, while being politically oppressed and economically exploited to such a horrifying degree, while its people, faced with starvation and many other catastrophes is struggling for its very survival? (p. 125)

A further development came from the voices of women theologians in The Circle of African Women Theologians (hereinafter referred to as The Circle) who exposed and confronted the exclusion of women's experiences of multiple oppressions in inculturation and liberation theologies. They not only critiqued African theologies but also pioneered new methodologies that generated liberation theologies for African women. According to Phiri and Nadar (2006:6), African women theologians are bilingual 'speaking language of academy and that of their communities not just linguistically, but culturally and socially'. In their work with grassroots women, The Circle adopted narrative story telling as a hermeneutical method. For Dube (2001), the effectiveness of this method is that it

provides new insights and methods of reading which widen the categories of inquiry because through the use of storytelling and its associated ideological inquiry, biblical stories are read in relation to socio-economic stories of the African continent where gender oppression is highlighted and new visions of the world are advanced. (p. 21)
Stories of women's experience led to what Phiri and Nadar (2006) described as 'narrative activism', which is the use of narratives to critique 'oppressive practices in African religio-

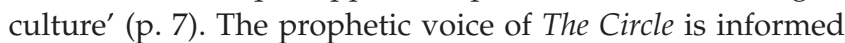
by action-oriented research based on women's experiences, which becomes the basis for social engagement and transformation.

From their extensive research and publication, African theologians challenged the hegemony of western theology, colonialism and apartheid, patriarchy, racism and exclusion of African knowledge through a range of methodologies that rooted their work in African cultures and contemporary experiences as an integral part of theological education. Based on this legacy, this article will argue that African theologians using old and new methodologies are well placed to respond to the many challenges emerging from commodification.

Similarly in higher education, decolonisation discourses as noted earlier confront issues of lack of access and the hegemony of western knowledge. The decolonisation theoretical framework is characterised by diversity as it draws for different experiences from former colonies. Pioneers from Africa include Fanon (1963) and Ngũgĩ (1986). Their works have been extensively studied and are beyond the scope of this paper, but it suffices to say that they are widely quoted in the contemporary decolonisation discourses. Of particular interest to this article is the generation of knowledge based on African pre-colonial traditions in dialogue with contemporary realities as a critical step in dislodging the hegemony of western knowledge and transforming universities into public goods for the benefit of Africa. A selection of themes from the global decolonisation discourse will be discussed, namely coloniality, construction of local knowledge based on pre-colonial traditions and contemporary experiences, pluriversalism and transformative knowledge.

Decolonisation is a contested term that is characterised by plurality and diversity as argued by Sium, Desai and Ritskes (2012:iii): 'the decolonising project seeks to reimagine and rearticulate power, change, and knowledge through a multiplicity of epistemologies, ontologies and axiologies. Decolonisation cannot take place without contestation'. This definition recognises that former colonies had different knowledge systems and experiences of colonisation that produce diversity and multiplicity within the decolonisation discourse.

Coloniality is a term used to describe the continuation of colonialism, albeit in different forms, in former colonies after independence. Ndlovu-Gatsheni (2012:1) defines coloniality as the 'invisible power structure that sustains colonial relations of exploitation and domination long after the end of direct colonialism'. That power according to Grosfoguel (2011:15) is exercised in the 'cultural, political, sexual and economic oppression/exploitation of subordinate racialised/ ethnic groups by dominant racial/ethnic groups with or 
without the existence of colonial administrations in contemporary global colonisation'. Thus, economic systems that produce and perpetuate inequalities in contemporary Africa have their roots in colonial/apartheid legacies. However, this does not discount the endemic corruption and mismanagement of resources by the ruling elite in contemporary Africa that has further exacerbated the current economic crisis. In addition, some of the oppressive hierarchies such as gender inequality and heterosexual bias are reinforced by Christian and cultural beliefs.

The construction of knowledge rooted in the African experience past and present is critical in countering western hegemonic claims to universality. Past knowledge is precolonial traditional beliefs and culture. Critical appropriation is necessary to counter romantic and static views about culture, which Makeng (1997:331) argues results in the 'mystification of culture' that reduces 'culture to a fixed past that is out of touch with realities of people'. Kanyoro (2002:13) defines culture as a 'double-edged sword. In some instances, culture is like the creed for the community identity. In other instances, culture is the main justification for difference, oppression and injustice' (p. 13). A critical appropriation of culture is necessary to ensure that the knowledge produced does not perpetuate oppressive hierarchies but is liberative.

When constructing knowledge from contemporary contexts, one needs to prioritise the voices and experiences of marginalised groups. Grosfoguel (2011) argues for this point as follows:

I believe that world-system analysis needs to decolonise its epistemology by taking seriously the subaltern side of the colonial difference: the side of the periphery, the workers, women, gays/lesbians, racialised/colonial subjects, homosexuals/ lesbians and anti-systemic movements in the process of knowledge production. (p. 24)

However, the construction of knowledge rooted and responsive to African realities does not constitute rejection of western knowledge but its hegemony, exclusivity and claim to universalism. Pluriversalim is a counter-paradigm that attributes equal status to multiple forms of knowledge. Mbembe (2015) defines pluriversalism as follows:

By pluriversity, many understand a process of knowledge production that is open to epistemic diversity. It is a process that does not necessarily abandon the notion of universal knowledge for humanity, but which embraces it via a horizontal strategy of openness to dialogue among different epistemic traditions. (p. 19)

Therefore, pluriversalism militates against the anti-pluralism of hegemonic western knowledge that recognises only one system of knowledge and advocates instead for multiple systems of knowledge that have equal recognition.

Knowledge production is not an end in itself but must result in transformation of the society from which it arises from. Decolonisation resists the division between knowledge and action particularly in contexts of oppression. Transformative praxis is defined by Sium et al. (2012) as follows:
Transformative praxis can be measured by our ability to show scholarly courage and imagination in taking our ideas off the bookshelf and acting on them. Decolonisation does not simply suggest that we refrain from becoming spectators to the knowledge we produce; it demands it. (p. viii)

It is evident from this discussion that there are shared commitments between African theologies and decolonisation discourses.

Commodification affects higher and theological education as well as government, business, students, civil society, academics and students; therefore, resistance must include these stakeholders. As mentioned in the introduction, it will be proposed that African theologians produce theologies of resistance in dialogues with stakeholders. In this regard, the methodology adopted by TCCRSA will be presented and analysed for its potential to be a theological method for a dialogue with stakeholders as a first step in producing theologies that resist and serve the wider social context as a critical aspect of restoring the purpose of theological education under threat from commodification.

\section{The Theological Colloquium on Church, Religion and Society in Africa}

The TCCRSA was the brain child of Agbonkhianmeghe E. Orobator (SJ), a Roman Catholic priest and academic. Orobator articulated the vision, methodology, objectives and outcome of TCCRSA in a statement entitled About Theological Colloquium on Church, Religion, and Society in Africa (TCCRSA). Below is a description of the vision of TCCRSA:

The Theological Colloquium on Church, Religion, and Society in Africa (TCCRSA) is a three-year theological research project in the currents of the fiftieth anniversary of Vatican II. The colloquium aims to develop, model, and sustain a new and innovative methodology and process of theological reflection, research, and study at the service of the African Church and the World Church. From 2013 to 2016, the colloquium will convene a community of African Catholic scholars doing theology or using Roman Catholic theological/ethical (re)sources in their academic disciplines to identify, analyse, and study a wide variety of issues in the African Church and society. (Orabator 2012:1)

Several defining characteristics can be gleaned from the vision statements, two of which will be discussed, namely, continuity with Vatican II and an innovative theological methodology that would generate knowledge in 'service of the African Church and the World Church'.

Vatican II was the 23 Catholic Ecumenical Council, which was convened by Pope John XXIII in Rome and lasted for 3 years from 1962 to 65 . In his opening statement, the Pope stated his intention for the council:

Today more than ever, we are called to serve mankind as such, and not merely Catholics; to defend above all and everywhere, the rights of the human person and not merely those of the 
Catholic Church [...]. It is not that the Gospel has changed: it is that we have begun to understand it better [...] The moment has come to discern the signs of the times, to seize the opportunity and to look far ahead. (Pope John Paul XXIII) ${ }^{3}$

The vision of the Pope was to transform the church internally and externally through 16 documents. Internal changes included recognition of the role of laity, transformation of liturgy, critical reading of the bible and emphasis on the church as the 'people of God'. External changes included relation to the world as engaged in the struggle for justice, human rights, dignity of all persons and promoting ecumenical and interfaith relationships and dialogues. A comprehensive discussion on Vatican II is beyond the scope of this paper, ${ }^{4}$ but two issues have particular relevance for TCCRSA, namely, the contextual nature-that is, it was in response to the contexts of that time-and the dialogical process across differences that included representatives from other churches, religions, laity and women.

By locating TCCRSA in the tradition of Vatican II and the African context, Orabator (2012) brought these two traditions together through a methodology that was communal, participatory, dialogical and inclusive of major stakeholders within and outside the Catholic Church in Africa:

The colloquium aims for a pan-African participation and representation of linguistic (French, Portuguese, and English speaking), gender (women and men), geographical (North Africa and sub-Saharan Africa: east, west, central, and south), generational (established theologians and young/new scholars), and ecclesial (laity, religious, clergy, and bishops) composition. It also includes African theologians in the Diaspora. (p. 1)

The style of the presentation was dialogical: 'Each colloquium will create a forum for conversation, listening, presentation of commissioned papers and responses, and joint working/ research sessions among participants.' Presenters were allocated an hour with 10 minutes for their presentation and the rest of the time was spent in conversation, critical analysis and reflections.

The objectives of TCCRSA through this methodology included the production of 'materials and resources for theological education and learning in Africa through the published volumes' and to 'Initiate and experiment with a new way of doing conversational, cross-disciplinary, collaborative, and multigenerational theology' (Orabator 2012:2). The structure and content of one of the books published through this process will be discussed as an illustration of the range of topics and their relevance for both the Church and the social context of Africa.

In the book published in 2015 entitled The Church We Want. Foundations, Theology and Mission of the Church in Africa. In Conversations on Ecclesiology, four themes were discussed,

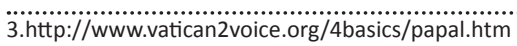

4.A comprehensive overview of Vatican II see A. Flannery, ed., Vatican Council II: Constitutions, Decrees, Declarations (repr. 1996) and Vatican Council II: Conciliar and Post Conciliar Documents (2 vol., repr. 1996). which illustrate the structure of the dialogues and the topics that were chosen by presenters for each section, namely:

- The African Church in the vision of Pope Francis: An example of a topic from this session that bridged the concern for justice that is central to the vision of Pope Francis with the need for justice in the African context: 'Reviving a Church of the Poor and for the Poor and reclaiming faith doing justice and seeking liberation. Convergence between Pope Francis and Jean-Marc Ela' (Mayemba 2015).

- Scriptural, Theological, Spiritual and Cultural Foundations of the Church: One of the unique features of this section is that most of the authors were women scholars, an indication of the intention to give equal space for women's voices. Teresa Okure's article entitled 'Becoming the Church of the New Testament' (Okure 2015:109) dealt with contentious issues of 'authority, ministry, ethics and morality' for the African church in dialogue with egalitarian model of the New Testament church.

- Ecclesia of Women and the Church in Africa: A section that focused exclusively on the voices and experiences of women. One example of innovative women's theologies is that of Cherinet in her article entitled 'Women in the Ethiopian Orthodox Tewahiho Church (EOTC)' who developed a 'woman and donkey theology' to describe the oppression of both women and donkeys and also their significant role as carriers of Jesus based on empirical research (Cherinet 2015:236-243).

- The Church in Contemporary Social and Ecumenical Contexts: The contributors in this session focused on different challenges facing the continent and consisted of women, men, priests, theologians and The Circle. Egan (2015) in his article entitled 'Facing the Crisis: On the Continent, in the Church. An Ecclesiology for an Africa in Distress' calls for dialogue among 'people of different faiths and denominations, African religion, women and the marginalized of our society, scientists, non-believers, NGOs and human rights organizations' (Egan 2015:281). Uzukwu (2015) argues for Christian unity in Africa as critical to confronting the multiple challenges in his article entitled 'A Theology of Christian Unity for the Church in Africa'.

The TCCRSA methodology was both structured and flexible because it set out the topics and then gave presenters freedom to choose topics. The diversity of participants brought different traditions, disciplines and constituents in dialogue with each other. One of the constraints for duplicating this method is finance, because without adequate funding it would be impossible to bring the range of participants across Africa and diasporas. However, finance need not be a limiting factor as the model can be contextualised to suit each context because the methodology can be duplicated, namely, bringing theologians in dialogue with multiple sectors and different stakeholders in a common vision to resist commodification and restore the vision and purpose of theological education in service of church and society. A community-level initiative 
would seem to be a good starting point that would then evolve to connect with other communities in exchange and dialogue. The process could be headed by existing ecumenical bodies that already have legitimacy among many churches and can mobilise easily. However, some irreconcilable doctrinal differences among churches may threaten the process, but this can be circumvented by framing discussions along themes where there is general consensus such as the dignity of all persons and the call to serve the common good. Theologians can then frame the outcomes of these discussions in ways that are critically compatible with their faith traditions. The public nature of this process would also generate interest by the general public that would further enhance the richness and diversity of the discourses. The model would need to be contextualised and owned by participants in order to achieve the goal of generating theologies rooted in the African experience represented by diverse voices and groups and committed to social transformation, a goal shared by African theologies and decolonial discourses. Commodification represents a new Kairos for theologians in Africa and theological education.

\section{Conclusion}

Commodification has become an inescapable global phenomenon that is affecting all of life as the market spreads its power beyond business to public and sacred institutions. Tertiary and theological institutions are experiencing multiple crises caused by commodification that strike at the heart of who they are as public and sacred institutions called to serve and transform society. In Africa as in former colonies, the additional challenge of the hegemony of western knowledge exacerbates the problems as local knowledge and experiences are excluded from these institutions. African theologians have historically challenged this hegemony through their wide range of contextual, inculturation, gender and liberation theologies. The decolonial discourses strive to do the same in tertiary institutions. Commodification has underscored the need to continue this work and generate contextual knowledge rooted in African realities and responsive to the multiple challenges facing the continent. No one discipline in higher education can do this alone and similarly no theological institution or theologians in a particular tradition can act alone. There is need to bring all stakeholders into dialogue. New methodologies are required and hence the choice of an African methodology adopted by TCCRSA as a possible model. A critical analysis of the model highlighted some of the strengths and limitations that require it to be contextualised. African theologians therefore have a critical role in mitigating the effects of commodification on theological education and thus contributing to the restoration of the vision and role of theological education in service of the church and society.

\section{Acknowledgements Competing interests}

The author declares that he has no financial or personal relationships which may have inappropriately influenced him in writing this article.

\section{References}

Amanze, J.N., 2012, 'The voicelessness of theology and religious studies in contemporary Africa: Who is to blame and what has to be done? Setting a new agenda', Missionalia 40(3), 189-204.

Anderson, A. \& Otwang, S., 1993, Tumelo. The faith of African Pentecostals in South Africa, University of Pretoria, Pretoria.

BBC, 2016, South Africa Prophet of Doom condemned, viewed 20 January 2017, from http://www.bbc.com/news/world-africa-38051923

Bediako, K., 2004, Jesus and the Gospel in Africa History and Experience, Orbis, Maryknoll, NY.

Bujo, B., 1990, African Christian morality at the age of inculturation, Pauline Publications, Nairobi.

Carrette, J. \& King, R., 2005, Selling spirituality. The silent takeover of religion, Routledge, Oxford.

Cherinet, H., 2015, 'Women in the Ethiopian Orthodox Tewahido Church (EOTC)', in A.E.S.J. Orobator (ed.), The church we want foundations, theology and mission of the church in Africa. Conversations on ecclesiology, pp. 235-246, Pauline Press, Nairobi.

Denis, P. \& Duncan, G., 2011, The native school that caused all the trouble, Cluster Publications, Pietermaritzburg.

De Wet, C.L., 2013, 'Entrepreneurial leadership training and theological education,' in M. Naidoo (ed.), Contested issues in training ministers in South Africa, pp. 127140, Sun Press, Stellenbosch.

Dube, M.W., 2001, 'Introduction: “Little Girl, Get Up!"' in N.J. Njoroge \& M.W. Dube (eds.), Talitha cum! Theologies of African women, pp. 1-24, Cluster Publications, Pietermaritzburg.

Dunsmuir, C. \& McCoy, M. 2013, 'Accreditation and ministerial formation: Serving two masters?' in M. Naidoo (ed.), Contested Issues in training ministers in South Africa, pp. 27-42, Sun Press, Stellenbosch.

Egan, A., 2015, 'Facing the Crisis: On the continent, in the Church: An ecclesiology for an Africa in distress,' in A.E.S.J. Orobator (ed.), The church we want foundations, theology and mission of the church in Africa. Conversations on ecclesiology, pp. 247-258, Pauline Press, Nairobi.

Einstein, F.M., 2008, Brands of faith. Marketing religion in a commercial age, Routledge, London.

Fanon, F., 1963, The wretched of the earth, Grove Press, New York.

Grosfoguel, R., 2011, 'Decolonising post-colonial studies and paradigms of politicaleconomy: Transmodernity, decolonial thinking, and global coloniality, TRANSMODERNITY: Journal of Peripheral Cultural Production of the Luso-Hispanic World 1(1), viewed 23 October 2016, from http://escholarship.org/uc/item/21k6t3fq http://dialogoglobal.com/texts/grosfoguel/Grosfoguel-Decolonising-Pol-Econ-andPostcolonial.pd

Gumbel, N., 2017, Alpha- Our story, viewed 20 January 2017, from http://alpha.org/ our-story/

Higgs, P., 2013, 'The African renaissance and the decolonisation of theological education', in M. Naidoo (ed.), Contested issues in training ministers in South Africa, pp. 43-56, Sun Press, Stellenbosch.

Igi-global dictionary, viewed 20 September, 2017, from http://www.igi-global.com/ dictionary/commodified-knowledge/34665

Kanyoro, M.R.A., 2002, Introducing feminist cultural hermeneutics. An African perspective (Introductions in Feminist Theology 9), Sheffield Academic Press, Sheffield.

Karpov, A.C., 2013, 'The commodification of education', Russian Education and Society 55(5), 75-90. https://doi.org/10.2753/RES1060-9393550506

Jacobs, M., 2009, 'On commodification and the governance of academic research', Minerva 47(4), 391-405. https://doi.org/10.1007/s11024-009-9134-2

Jantzen, G.M., 1994, 'Feminists, philosophers, and mystics', Feminist Philosophy of Religion 9(4), 186-206. https://doi.org/10.1111/j.1527-2001.1994.tb00655.x

Landman, C., 2013, 'Theological education in South Africa', in I.A. Phiri \& W. Werner (eds.), Handbook of theological education in Africa, pp. 239-245, Cluster, Pietermaritzburg.

Makgoba, M. \& Seepe, S., 2004, 'Knowledge and identity: An African vision of higher education transformation', in S. Seepe (ed.), Towards an African identity of higher education, pp. 13-58, Vista University and Skotaville Media, Pretoria.

Martey, E., 1993, African theology: Inculturation and liberation, Orbis Books, Maryknowll, NY.

Makeng, J.M., 1997, 'Of the good use of tradition: Keeping the critical perspective in African Philosophy', in E.C. Ese (ed.), Postcolonial African philosophy a critical reader, pp. 324-338, Blackwell Publishers, Cambridge, MA.

Mayemba, B., 2015, 'Reviving a church of the poor and for the poor and reclaiming faith doing justice and seeking liberation: Convergence between Pope Francis and Jean-Marc Ela', in A.E.S.J. Orobator (ed.), The church we want foundations, theology and mission of the church in Africa. Conversations on ecclesiology, pp. 69-82, Pauline Press, Nairobi.

Mbembe, A., 2015, Decolonising knowledge and the question of the archive viewed 06 November 2016, from http://wiser.wits.ac.sa/system/files/Achille $\% 20$ Mbembe $\% 20-\% 20$ Decolonising $\% 20$ Knowledge $\% 20$ and $\% 20$ the $\% 20$ Question $\% 20$ of $\% 20$ the $\% 20$ Archive.pdf

Merriam-Webster dictionary, viewed 20 September 2016, from https://www. merriam-webster.com/dictionary/commodify

Miller, T., 2003, 'Governmentality or commodification? US higher education', Cultural Studies 17(6), 897-904. https://doi.org/10.1080/0950238032000150084 
Ndlovu-Gatsheni, S.J., 2012, Coloniality of Power in Development Studies and the Impact of Global Imperial Designs on Africa1 Sabelo J. Ndlovu-Gatsheni Archie Mafeje Research Institute (AMRI) and Department of Development Studies Mafeje Research Institute (AMRI) and Department of Development Studies University of South Africa Inaugural Lecture deliver
South Africa, Senate Hall, Pretoria, 16 October 2012.

Ngũgĩ, T., 1986, Decolonising the mind: The politics of language in African literature, J. Currey, Chicago, IL.

Okure, T., 2015, 'Becoming the church of the New Testament', in A.E.S.J. Orobator (ed.), The church we want foundations, theology and mission of the church in Africa. Conversations on ecclesiology, pp. 109-121, Pauline Press, Nairobi.

Phiri, I.A., \& Nadar, S., 2006, 'Introduction: Treading softly but firmly, in I.A. Phiri \& S. Nadar (eds.), African women, religion, and health. Essays in honour of Mercy Amba Ewudsiwa Oduyoye, pp. 1-16, Cluster Publications, Pietermaritsburg.

Naidoo, M., 2013, 'Persistent issues impacting on the training of ministers in the South African Context', Scriptura 112(1), 1-16. https://doi.org/10.7833/112-0-57

Naidoo, M., 2015, 'Introduction', in M. Naidoo (ed.), Contested issues in training ministers in South Africa, pp. 1-10, Sun Press, Stellenbosch.

O'Byrne, D. \& Bond, C., 2014, 'Back to the future: The idea of a university revisited, Journal of Higher Education Policy \& Management 36(6), 571-584. https://doi.or g/10.1080/1360080X.2014.957888

Orabator, A.E.S.J., 2012, About theological colloquium on church, religion, and society in Africa (TCCRSA) unpublished pape

Pope Paul VI., 1965, 'Decree on priestly training. Optatam Totius', viewed 29 April 2016, from http://www.vatican.va/archive/hist_councils/ii_vatican_council/ documents/vat-ii_decree_19651028_optatam-totius_en.htm

Sall, H.N. \& Ndjaye, B.D., 2007, 'Higher education in Africa: Between perspectives opened by the Bologna process and the commodification of education', European Education 39(4), 43-57. https://doi.org/10.2753/EUE1056-4934390403
Schwartzman, R., 2013, 'Consequences of commodifying education', Academic Exchange Quarterly 17(3), 1-7.

Sium, A., Desai, C. \& Ritskes, E., 2012, 'Towards the "tangible unknown": Decolonisation and the Indigenous future', Decolonisation: Indigeneity, Education \& Society 1(1), i-xiii.

Stokel-Walke, C., 2017, How smart phones and social media are changing Christianity, viewed 01 March 2017, from http://www.bbc.com/future/story/20170222-howsmartphones-and-social-media-are-changing-religion

Tehram, N., 2015, Why is my curriculum white?, viewed 29 April 2017, from https:// theoccupiedtimes.org/? $\mathrm{p}=14056$

Uzukwu, E., 2015, 'A theology of Christian unity for the church in Africa', in A.E.S.J. Orobator (ed.), The church we want foundations, theology and mission of the church in Africa. Conversations on ecclesiology, pp. 283-295, Pauline Press, Nairobi.

Wahl, W.P., 2013, 'Towards relevant theological education in Africa: Comparing the international discourse with contextual challenges', Acta Theologica 33(1), 266293. https://doi.org/10.4314/actat.v33i1.14

Venter, R., 2016, 'Theology and the (post-) apartheid university: Mapping discourses, interrogating transformation', Transformation in Higher Education 1(1), a5. https://doi.org/10.4102/the.v1i1.5

Warren, R., 2017, Purpose driven church, viewed 20 January 2017, from http:// pastors.com/

West, C., 1993, Race matters, Beacon Press, Boston, MA.

Whitt, L., 2009, Science, colonialism, and indigenous peoples. The cultural politics of law and knowledge, Cambridge University, Cambridge.

Yang, R., 2006, 'The commodification of education and its effects on developing countries: A focus on China,' Journal Für Entwicklungspolitik herausgegeben vom Mattersburger Kreis für Entwicklungspolitik an den österreichischen Universitäten xxii, 52-69. 